\title{
Cloning and identification of novel hydrolase genes from a dairy cow rumen metagenomic library and characterization of a cellulase gene
}

\author{
Xia Gong ${ }^{1,2}$, Robert J Gruninger ${ }^{1}$, Meng Qi ${ }^{1}$, Lyn Paterson ${ }^{1}$, Robert J Forster ${ }^{1}$, Ron M Teather ${ }^{1}$
} and Tim A McAllister ${ }^{1 *}$

\begin{abstract}
Background: Interest in cellulose degrading enzymes has increased in recent years due to the expansion of the cellulosic biofuel industry. The rumen is a highly adapted environment for the degradation of cellulose and a promising source of enzymes for industrial use. To identify cellulase enzymes that may be of such use we have undertaken a functional metagenomic screen to identify cellulase enzymes from the bacterial community in the rumen of a grass-hay fed dairy cow.

Results: Twenty five clones specifying cellulose activity were identified. Subcloning and sequence analysis of a subset of these hydrolase-positive clones identified 10 endoglucanase genes. Preliminary characterization of the encoded cellulases was carried out using crude extracts of each of the subclones. Zymogram analysis using carboxymethylcellulose as a substrate showed a single positive band for each subclone, confirming that only one functional cellulase gene was present in each. One cellulase gene, designated Cel14b22, was expressed at a high level in Escherichia coli and purified for further characterization. The purified recombinant enzyme showed optimal activity at $\mathrm{pH} 6.0$ and $50^{\circ} \mathrm{C}$. It was stable over a broad $\mathrm{pH}$ range, from $\mathrm{pH} 4.0$ to 10.0. The activity was significantly enhanced by $\mathrm{Mn}^{2+}$ and dramatically reduced by $\mathrm{Fe}^{3+}$ or $\mathrm{Cu}^{2+}$. The enzyme hydrolyzed a wide range of beta-1,3-, and beta-1,4-linked polysaccharides, with varying activities. Activities toward microcrystalline cellulose and filter paper were relatively high, while the highest activity was toward Oat Gum.
\end{abstract}

Conclusion: The present study shows that a functional metagenomic approach can be used to isolate previously uncharacterized cellulases from the rumen environment.

Keywords: Endoglucanase, Ruminal microorganisms, BAC library, Dairy cow

\section{Background}

Cellulose is a principal component of plant cell walls. Efficient cellulose hydrolysis requires the synergistic activity of three classes of cellulase: endo-1,4- $\beta$-glucanase (EC3.2.1.4), cellobiohydrolase (EC3.2.1.91) and $\beta$-glucosidase (EC3.2.1.21). In recent years, interest in plant cell-walldegrading enzymes, including cellulases, has increased due to the numerous potential industrial applications of these enzymes [1]. They have been widely applied in the textile and laundry, food and feed, pulp and paper,

\footnotetext{
* Correspondence: tim.mcallister@agr.gc.ca

'Agriculture and Agri-Food Canada, Lethbridge Research Centre, Lethbridge, Alberta T1J 4B1, Canada

Full list of author information is available at the end of the article
}

baking, waste treatment, and biomass-based alcohol production industries [2]. Growing concerns about the worldwide shortage of non-renewable fuel and rising oil prices as well as greenhouse gas emissions have led to an increasing interest in the development of alternative environmentally-friendly biofuels [3].

Cellulases are produced by a variety of organisms, including archaea, prokaryotes, fungi, plants, and animals. The most effective known natural systems for rapid biomass conversion, however, involve complex communities of microorganisms, primarily prokaryotes and fungi, maintained in a symbiotic relationship with an animal host [4]. This apparent need for complexity is a consequence of the biochemical intricacy of the biomass that serves as




the fermentation substrate, a complex, physically and chemically linked mixture of cellulose, hemicellulose, xylan, waxes, and lignins.

Perhaps one of the best characterized examples of an effective complex biomass degrading community is that harboured within the rumen [4]. The natural diet of ruminants is mainly plant material, and most of the digestion of plant mass takes place under anaerobic conditions within the rumen. Many hydrolase genes have been isolated and characterized from cultivable ruminal microbes [5] however, it is generally accepted that a large proportion of the microorganisms in many complex natural environments remain uncultured [6,7]. Even for the relatively intensively studied rumen microbial community it is estimated that more than $85 \%$ of its members have still not been cultivated [5]. This estimate is based on the phylogenetic diversity of rumen microbial communities in deer, sheep and cattle as revealed by $16 \mathrm{~S} / 18 \mathrm{~S}$ rDNA amplification sequencing techniques, denaturing gradient gel electrophoresis, terminal restriction fragment length polymorphism, and suppressive subtractive hybridization methods [8-12]. This unexplored microbial diversity represents an untapped source of potentially novel and unique enzymatic activities and metabolic pathways that can be applied to industrial biomass conversion $[7,13,14]$.
Metagenomic approaches have been widely used to isolate novel biocatalysts from environmental samples [15]. Several metagenome derived hydrolase genes have been identified in metagenomic libraries prepared from various environmental samples, including those from the rumen [14,16-19]. The goals of this study were to clone and characterize novel cellulases from the rumen microbial community. To this end, a functional screen of a bacterial artificial chromosome (BAC) metagenomic library from the cow rumen was implemented to identify proteins involved in the degradation of polysaccharides by uncultivated rumen microorganisms.

\section{Results}

Metagenomic library construction and screening

A metagenomic BAC library of $\sim 6000$ clones was constructed with high molecular weight DNA isolated by a freeze grinding technique from dairy cow rumen samples. Screening for hydrolase activities resulted in the identification of ten independent clones expressing carboxymethyl cellulase (CMCase) activities, nine expressing $\beta$-glucosidase activities and seven expressing hydrolase activities for other substrates were isolated (Table 1).

The total library encompassed an estimated $900 \mathrm{Mb}$ of insertion DNA. The positive rate of hydrolase activity in the library was approximately $0.15 \%$ of examined clones,

Table 1 Putative glycosyl hydrolases obtained from subclones expressing cellulase activities from the cow rumen metagenome

\begin{tabular}{|c|c|c|c|c|}
\hline BAC clone & Subclone & First blastx match & Expect & Identity/Similarity(\%) \\
\hline $13-103$ & p21 & B-glucosidase (B. formatexigens DSM 14469, ZP_05346034) & $2.00 \times 10^{-23}$ & $37 / 51$ \\
\hline 13-N07 & p296 & Cel8B (F. succinogenes, ABU45499) & $8.00 \times 10^{-176}$ & $89 / 94$ \\
\hline 14-B22 & $\mathrm{p} 13$ & CH5 (Uncultured microorganism, AFO64636) & 0 & $78 / 86$ \\
\hline 14-F03 & p75 & Cel9B (F. succinogenes, AAC44386) & 0 & $71 / 83$ \\
\hline 3-M02 & $\mathrm{p} 28$ & Cel9B (F. succinogenes, AAC44386) & 0 & $63 / 75$ \\
\hline $3-N 18$ & $\mathrm{p} 20$ & B-glucosidase (P. bergensis DSM 17361, ZP_06005092) & 0 & $70 / 79$ \\
\hline $3-\mathrm{N} 18$ & p13 & B-glucosidase (Bacteroides sp. 2_1_7, ZP_05286991) & $2.00 \times 10^{-115}$ & $50 / 66$ \\
\hline $3-P 24$ & $\mathrm{p} 44$ & Cel9B (F. succinogenes, AAC44386) & 0 & $71 / 83$ \\
\hline 4-E05 & p13 & B-glucosidase (P. bergensis DSM 17361, ZP_06005092) & $4 \times 10^{-29}$ & $60 / 72$ \\
\hline 4-E05 & p10 & $\beta$-xylosidase (uncultured rumen bacterium,CAP07659) & $1 \times 10^{-117}$ & $60 / 71$ \\
\hline $5-\mathrm{CO}$ & $\mathrm{p} 44 \mathrm{c}$ & Cel5H (F. succinogenes, ABU45500) & $7.00 \times 10^{-60}$ & $39 / 56$ \\
\hline $5-105$ & $\mathrm{p} 20$ & $\begin{array}{l}\beta \text {-glucosidase related glycosidases } \\
\text { (Ruminococcus obeum A2-162, CBL22609) }\end{array}$ & $9.00 \times 10^{-13}$ & $31 / 50$ \\
\hline $5-K 18$ & p52 & ß-glucosidase (B. formatexigens DSM 14469, ZP_05346034) & $2.00 \times 10^{-36}$ & $43 / 56$ \\
\hline $6-\mathrm{CO}$ & p2 & Cel5H (F. succinogenes, ABU45500) & 0 & $53 / 69$ \\
\hline $6-110$ & p35 & Cel5H (F. succinogenes, ABU45500) & 0 & $53 / 69$ \\
\hline $6-K 13$ & p41 & Cel5H (F. succinogenes, ABU45500) & $7.00 \times 10^{-60}$ & $39 / 56$ \\
\hline 6-L14 & $\mathrm{p} 61$ & Cel5H (F. succinogenes, ABU45500) & $1.00 \times 10^{-5}$ & $40 / 60$ \\
\hline 7-A06 & p24 & putative xylanase (Bacteroides fragilis 3_1_12, ZP_05281078) & $2.00 \times 10^{-9}$ & $29 / 45$ \\
\hline 7-D10 & p19 & ß-glucosidase (P. bergensis DSM 17361, ZP_06005092) & 0 & $65 / 75$ \\
\hline 7-L24 & p1 & ß-glucosidase (P. bergensis DSM 17361, ZP_06005092) & $4.00 \times 10^{-116}$ & $62 / 73$ \\
\hline
\end{tabular}




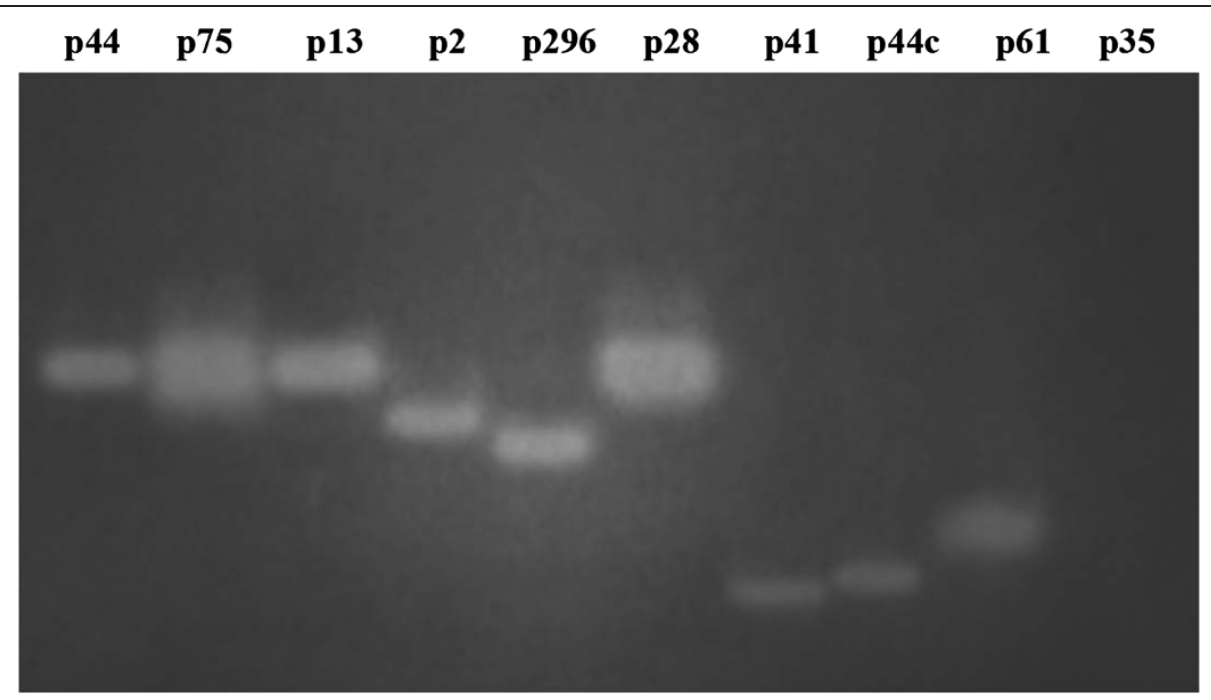

Figure 1 Zymogram analysis of the 10 cloned cellulases in native polyacrylamide gel eletrophoresis. CMCase activities were detected on CMC agar replica plates of the polycrylamide gel.

or one expressed hydrolase gene per $10 \mathrm{Mb}$ of insert DNA. Subcloning and sequence analysis of a subset of these hydrolase-positive clones identified twenty endoglucanase genes (Table 1). Predicted amino acid sequences generally indicated moderate to low homology and similarity (average $70 \%$ ) to the cellulases in NCBI databases. Ten endoglucanases with CMCase activity were selected for further study. Glycoside hydrolase families 5, 8 and 9 were represented by six, one, and three of these ten endoglucanases, respectively (Table 1 ).

\section{Characterization of enzyme activities for the subcloned cellulases}

On the basis of a CMCase zymogram with native PAGE, each of the subclones selected for further study appeared to produce only a single active protein which was responsible for the observed activity, except for $\mathrm{p} 35$ where no positive band was observed (Figure 1). The CMCase activity of the 10 cellulases was assayed over a range of $\mathrm{pH}$ values and temperatures. The $\mathrm{pH}$ optima ranged from 6 to 7, while the optimal temperatures for all were between 40 to $50^{\circ} \mathrm{C}$ (Table 2). All the cellulases were also tested for their substrate specificities (Table 3). The CMCases showed a diverse range of activity with six showing maximal activity toward oat gum, one toward barley glucan, two toward $\mathrm{CMC}$, and one toward lichenan. The activity of these enzymes towards methyl cellulose, filter paper, Avicel, and xylan from birch wood or oat spelt ranged widely. Among the subcloness, $\mathrm{p} 2$ and p13 (BAC clones 6-C02 and 14-B22) showed the highest activities towards Avicel and filter paper of the CMCases examined.

\section{Overexpression of $\mathrm{C} 6 \mathrm{CO} 2$ and Cel14b22}

Due to the high activity against crystalline cellulose the cellulases, encoded in subclones $\mathrm{p} 2$ and $\mathrm{p} 13$ were selected for further study. The genes, designated by the names of the original BAC clones as $\mathrm{C} 6 \mathrm{cO} 2$ and Cel14b22, had lengths of $1680 \mathrm{bp}$, encoding for 559 amino acids, and 2679 bp, encoding for 892 amino acids, respectively. SMART analysis of deduced amino acid sequences of the C6c02 and Cel14b22 cellulase genes showed that each contained a glycosyl hydrolase (GH) family 5 catalytic domain and a signal peptide. The $\mathrm{C} 6 \mathrm{c} 02$ contained a CBM_II, but Cel14b22 contained a C-terminal module with no significant homology to known CBMs. Unfortunately, despite our best efforts the overexpressed product of $\mathrm{C} 6 \mathrm{c02}$ was insoluble and could not be purified. SDSPAGE analysis of the crude extract of Cel14b22 showed expression of $6 \mathrm{xHis}$ tagged proteins, as observed by the appearance of an extra protein band migrating at about $63 \mathrm{kDa}$ upon induction (Figure 2, lane 2). The size of the expressed Cel14b22 was similar to the molecular mass calculated from the amino acid sequences $(63 \mathrm{kDa})$. After purification with the Ni-NTA column and desalting with PD-10 columns, a single band was shown on the

Table 2 Optimal pH values and temperatures of the cellulases cloned from metagenomic BAC library of the cow rumen

\begin{tabular}{lcccccccccc}
\hline Cellulase & $\mathbf{p 4 4}$ & $\mathbf{p 7 5}$ & $\mathbf{p 1 3}$ & $\mathbf{p 2}$ & $\mathbf{p 3 5}$ & $\mathbf{p 4 4 c}$ & $\mathbf{p 6 1}$ & $\mathbf{p 2 9 6}$ & $\mathbf{p 4 1}$ & $\mathbf{p 2 8}$ \\
\hline Optimal $\mathrm{pH}$ & 6.5 & 6.5 & 6.0 & 6.5 & 6.5 & 6.5 & 6.5 & 7.0 & 7.0 & 6.5 \\
Optimal temperature $\left({ }^{\circ} \mathrm{C}\right)$ & 45 & 45 & 50 & 50 & 50 & 50 & 50 & 50 & 40 & 40 \\
\hline
\end{tabular}


Table 3 Substrate specificity of the protein crude extracts from cultures of subclones expressing cellulase activity

\begin{tabular}{|c|c|c|c|c|c|c|c|c|c|c|}
\hline \multirow[t]{2}{*}{ Substrate } & \multicolumn{10}{|c|}{ Relative specific activity (\%) } \\
\hline & p44 & p75 & p13 & p2 & p35 & p44c & p61 & p296 & $\mathrm{p} 41$ & p28 \\
\hline Barley glucan ((1-3,1-4)- $\beta$-D-glucan) & 100 & 5.9 & 15.6 & 9.2 & 5.1 & 20.3 & 11.1 & 6.5 & 2.4 & 5.3 \\
\hline Lichenan ((1-3,1-4)- $\beta$-D-glucan) & 80.4 & 5.6 & 23.0 & 5.1 & 100 & 28.4 & 6.0 & 23.9 & 1.1 & 3.3 \\
\hline Carboxymethylcellulose (1,4- $\beta$-D-glucan) & 53.5 & 1.2 & 100 & 100 & 50.5 & 73.0 & 42.2 & 78.9 & 16.8 & 7.5 \\
\hline Methyl cellulose (1,4- $\beta$-D-glucan) & 5.3 & 0.4 & 12.5 & 14.2 & 6.5 & 8.7 & 5.8 & 14.1 & 0.5 & 0.3 \\
\hline Avicel (1,4- $\beta$-D-glucan) & 18.0 & 0.8 & 44.8 & 72.6 & 21.7 & 21.1 & 6.9 & 62.9 & 0.7 & 1.2 \\
\hline Xylan from birchwood (1,4-3-D-xylan) & 5.3 & 0.3 & 21.3 & 16.8 & 6.2 & 4.9 & 1.2 & 18.1 & 0.2 & 0.2 \\
\hline Xylan from oat spelt (1,4- $\beta$-D-xylan) & 12.3 & 0.6 & 27.7 & 18.8 & 11.4 & 10.4 & 5.2 & 29.8 & 0.6 & 1.4 \\
\hline Oat gum ((1-3,1-4)- $\beta$-D-glucan) & 5.9 & 100 & 71.0 & 14.9 & 45.5 & 100 & 100 & 100 & 100 & 100 \\
\hline Filter paper & 4.1 & 0.2 & 11.1 & 7.9 & 4.6 & 3.4 & 1.0 & 11.8 & 0.1 & 0.2 \\
\hline
\end{tabular}

SDS-PAGE gel corresponding with the size of the enzyme, suggesting that the enzyme was purified to homogeneity (Figure 2, lane 3).

\section{Characterization of the purified recombinant Cel14b22}

The activity of Cel14b22 towards CMC was optimal at $\mathrm{a} \sim \mathrm{pH} 6.0$ and $50^{\circ} \mathrm{C}$, consistent with the optimal conditions for the crude protein extract from subclone p13.
The Cel14b22 enzyme retained more than $60 \%$ of its activity after storage at $4^{\circ} \mathrm{C}$ for $24 \mathrm{~h}$ at $\mathrm{pHs}$ ranging from 4 to 10 (Figure $3 \mathrm{a}, \mathrm{b}$ ). The enzyme was stable for $1 \mathrm{~h}$ at temperatures below $50^{\circ} \mathrm{C}$ with over $80 \%$ of the activity remaining, but activity was completely lost at temperatures above $55^{\circ} \mathrm{C}$ (Figure $3 \mathrm{c}, \mathrm{d}$ ). The $\mathrm{K}_{m}$ and $\mathrm{V}_{\text {max }}$ of the recombinant Cel14b22 towards CMC were $13.23 \mathrm{mg} / \mathrm{mL}$ and $178.57 \mathrm{U} / \mathrm{mg}$, respectively.







Figure 3 Effects of $\mathrm{pH}$ and temperature on the activity and the stability of Cel14b22. a) Effect of pH on activity of Cel14b22. b) pH stability of Cel14b22. c) Effect of temperature on the activity of Cel14b22. d) Temperature stability of Cel14b22. The error bars represent the standard deviation of triplicate measurements.

Substrate specificity of the recombinant Cel14b22 was determined under optimal conditions with $1 \%$ polysaccharides (Table 4). The enzyme had the highest activities towards barley oat gum, and showed low activity toward insoluble celluloses.

The effects of metal ions, EDTA, and SDS on CMCase activity were also determined. $\mathrm{Mn}^{2+}$ enhanced the enzymatic activity to $155 \%$, whereas $\mathrm{Cu}^{2+}$ and $\mathrm{Fe}^{3+}$

Table 4 Substrate specificity of Cel14b22

\begin{tabular}{|c|c|c|}
\hline Substrates & $\begin{array}{c}\text { Specific } \\
\text { activity } \\
(\mathrm{U} / \mathrm{mg}) \pm S D\end{array}$ & $\begin{array}{c}\text { Relative } \\
\text { activity (\%) }\end{array}$ \\
\hline  & $368.22 \pm 2.77$ & 100 \\
\hline Barley $\beta$-glucan ((1-3,1-4)- $\beta$-D-glucan) & $172.94 \pm 9.92$ & 47 \\
\hline Carboxymethyl cellulose (1,4- $\beta$-D-glucan) & $110.42 \pm 4.07$ & 30 \\
\hline 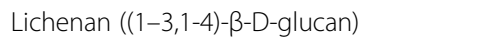 & $86.48 \pm 4.45$ & 23 \\
\hline Oat spelt xylan (1,4- $\beta$-D-xylan) & $39.79 \pm 3.62$ & 11 \\
\hline Methyl cellulose (1,4- $\beta$-D-glucan) & $39.41 \pm 3.72$ & 11 \\
\hline Birchwood xylan (1,4- $\beta$-D-xylan) & $38.29 \pm 5.44$ & 10 \\
\hline Avicel (1,4- $\beta$-D-glucan) & $21.96 \pm 3.40$ & 6 \\
\hline Filter paper & $20.78 \pm 6.97$ & 6 \\
\hline
\end{tabular}

${ }^{a}$ The incubation time for activity measurement was $15 \mathrm{~min}$, performed in triplicate and the standard deviations were calculated. dramatically reduced enzyme activity, to $21 \%$ and $12 \%$, respectively. $\mathrm{Cr}^{2+}, \mathrm{Zn}^{2+}$ and $\mathrm{Mg}^{2+}$ had only slight inhibitory effects, and $\mathrm{Co}^{2+}, \mathrm{Ca}^{2+}, \mathrm{K}^{+}$and $\mathrm{Na}^{+}$did not alter activity. The chelating agent EDTA slightly inhibited activity (to $84 \%$ ), whereas SDS completely abolished the activity of Cel14b22 (Table 5).

\section{Discussion}

This study was in part undertaken to assess the utility of a freeze grinding approach to the recovery of representative, high molecular weight, metagenomic DNA from the rumen microbial community and to identify cellulases that may be of industrial interest. This approach had a particular focus on the quantitative recovery of DNA from the largely fibre-associated members of the rumen microbial community involved in plant fibre degradation. The test BAC library comprised $\sim 6000$ clones constructed with high molecular weight DNA isolated by a freeze grinding technique from dairy cow rumen samples. The total library encompassed an estimated $900 \mathrm{Mb}$ of insertion DNA. The positive rate of hydrolase activity expression in the library was approximately $0.15 \%$ of the tested clones, or one expressed hydrolase gene per $10 \mathrm{Mb}$ of insert DNA. For polysaccharidases, the rate was about 1 hydrolase gene per $25 \mathrm{Mb}$ of insert 


\begin{tabular}{|c|c|c|}
\hline Reagent & Concentration & $\begin{array}{l}\text { Relative activity (\%) } \\
\pm \text { standard deviation }\end{array}$ \\
\hline Control & - & 100 \\
\hline $\mathrm{CoCl}_{2}$ & $10 \mathrm{mM}$ & $107.9 \pm 4.7$ \\
\hline $\mathrm{CaCl}_{2}$ & $10 \mathrm{mM}$ & $102.2 \pm 5.4$ \\
\hline $\mathrm{CrCl}_{2}$ & $10 \mathrm{mM}$ & $68.4 \pm 1.6$ \\
\hline $\mathrm{CuSO}_{4}$ & $10 \mathrm{mM}$ & $21.4 \pm 0.6$ \\
\hline $\mathrm{ZnCl}_{2}$ & $10 \mathrm{mM}$ & $61.5 \pm 0.7$ \\
\hline $\mathrm{MgCl}_{2}$ & $10 \mathrm{mM}$ & $85.0 \pm 4.6$ \\
\hline $\mathrm{FeCl}_{3}$ & $10 \mathrm{mM}$ & $12.8 \pm 2.3$ \\
\hline $\mathrm{MnCl}_{2}$ & $10 \mathrm{mM}$ & $155.2 \pm 5.4$ \\
\hline $\mathrm{KCl}$ & $10 \mathrm{mM}$ & $103.7 \pm 6.0$ \\
\hline $\mathrm{NaCl}$ & $10 \mathrm{mM}$ & $105.5 \pm 4.4$ \\
\hline EDTA & $1 \mathrm{mM}$ & $84.0 \pm 4.0$ \\
\hline SDS & $1 \% \mathrm{w} / \mathrm{v}$ & 0 \\
\hline
\end{tabular}

DNA. This rate is very similar to that which would be expected from the data of Brulc et al. [16], who used a pyrosequencing approach, where examination of $\sim 25000 \mathrm{Mb}$ of sequence data identified $\sim 1000 \mathrm{GH}$ family sequences. This result suggests that the freeze grinding approach indeed provides a representative sample of the rumen metagenome while facilitating a functional screening approach.

We identified twenty five cellulase positive BAC clones (inluding nine $\beta$-glucosidases). The high number of hydrolytic clones is consistent with the adaptation of the rumen microbial community for the digestion of plant cell-wall material in the rumen $[16,17]$. However, cellobiohydrolases or multi-domain cellulases were not retrieved in this study, most likely because that they did fold appropriately in host $E$. coli, were not expressed, or their expression level was too low to be detected. However, pyrosequencing of BAC clones expressing hydrolase activities does allow the identification of clustered genes which might be functionally related to the expressed activity. This is apparent in BAC clone 3-N18, where genes for a xylanase, esterase and 3 putative glycoside hydrolases grouped together. BAC clones that show homologies to Fibrobacter succinogenes, a prominent cellulolytic bacterium in the rumen, do not exhibit this pattern, as has been noted in the $F$. succinogenes genome sequence [20].

The recombinant enzyme Cel14b22 was overexpressed and purified. It comprises an N-terminal signal peptide (amino acids 1-19), a catalytic module belonging to the glycoside hydrolase family 5 (amino acids 40-339), and a C-terminal module with no known functional homologue. The conserved catalytic residues were identified by homology to other GH5 family members as the
Glu 178 and Glu 289 residues. As with the two catalytic residues, the other six well-established conserved residues in the GH5 family were also verified in the Cel14b22 sequence: Arg 83, His 125, Asn 177, His 253, Tyr 255 and Trp 331. Studies suggested that these eight residues are conserved in all GH5 family enzymes [21,22].

The C-terminal module (amino acids 340-559) showed no significant homology to known CBMs, but it shared $28 \%$ identity with the C-terminal module of another GH5 cellulase, ACA61140. This GH5 family cellulase, from another uncultured ruminal microorganism, also shows no significant homology to known CBMs [23]. Almost all CBMs studied to date contain surface exposed aromatic rings, which have been shown to be involved in the recognition and binding of polysaccharides. Aromatic amino acid residues form face-to-face hydrophobic stacking interactions in which a tryptophan or tyrosine ring interacts with the nonpolar face of a sugar ring [24]. An alignment of the module with a xylanase/cellulase from the ruminal bacterium Prevotella ruminicola 23 (1923215A, aa 375-584), uncultured ruminal microbial cellulases ACA61137 (aa 334-546) and ACA61140 (aa 334-537aa), and uncultured ruminal bifunctional/ cellulase enzymes ABB46200 (aa 715-917) and ADA62505 (aa 721-919) showed that nine aromatic amino acid residues were conserved in the sequences (Figure 4) with the two tryptophan residues possibly involved in cellulose binding [25]. The observation that Cel14b22 has activity towards Avicel and filter paper also suggests that the C-terminal module has CBM activity.

Cel14b22 shares physico-chemical properties with many other family 5 endoglucanases. Several cellulases from fungi [26] and bacteria [27,28] show optimal hydrolytic activities under similar conditions. Cel14b22 is active over a wide range of $\mathrm{pH}$, retaining $40 \%$ of its activity between $\mathrm{pH} 4.5$ and $\mathrm{pH}$ 9.5, and it is stable even at $\mathrm{pH} 10.0$. The Cel14b22 endoglucanase was only partially inhibited when incubated in $1 \mathrm{mM}$ EDTA, suggesting that Cel14b22 does not absolutely require divalent cations to degrade CMC. Furthermore, addition of $10 \mathrm{mM} \mathrm{Ca}^{2+}$ or $\mathrm{Co}^{2+}$ to the incubation buffer did not alter Cel14b22 activity. This is the case for the majority of glycoside hydrolases from family 5 , whereas these cations seem to stimulate several family 9 glycoside hydrolases $[29,30]$. The metal ion $\mathrm{Mn}^{2+}$ did enhance enzyme activity, which is consistent with most cellulases [31-33]. It is known that different metallic ions, such as $\mathrm{Fe}^{3+}, \mathrm{Cu}^{2+}, \mathrm{Zn}^{3+}$, exert an inhibitory effect on family 5 glycoside hydrolases $[30,34]$, especially those from ruminal cellulolytic bacteria. This was also observed with Cel14b22 with $\mathrm{Zn}^{3+}$, $\mathrm{Cu}^{2+}$ and $\mathrm{Fe}^{3+}$. The activity of Cel14b22 was significantly higher toward mixed-linkage $\beta$-glucans from barley and oats than toward $(1,4)-\beta$-glucans, including CMC. Activity was also lower toward the mixed-linkage $\beta$-glucan 


\begin{tabular}{|c|c|}
\hline C14B22 & TLPAFHQADLAQTLIKAYYGSTDGYKYPTPDDFQ- - - TVYTVSYNS \\
\hline ACA61137 & SLPVFNQADLAETLIKAYYGSTSGYKFPSSSSTR- - - IVYTVKYNQ \\
\hline $1923215 \mathrm{~A}$ & SLPAFNQPDLAERIAKAYHGSDFAGTYPTENDFN- - - ISYLVEYEK \\
\hline ADA62505 & TYPAFTQPPDLALKMLQAYHGDSWNPYLPDAKDFPDGKITSATVNYI \\
\hline ABB4 6200 & TYPAFTQPDLALKMLQAYHGDSWNPYLPDAKDFPEGKITSATVNF \\
\hline ACA61140 & SEPAFNQPDLAETLTKAYHGSAFEGKYPVHDSSKG - - TVAFEGEK' \\
\hline C14B22 & SATLKLTEYKGVRIELDND-YSSKLQIKVYGDKDGKNTDGSDKF \\
\hline ACA61137 & TA-VNLSGYKGIRVEMADDSYAGKVQVKVYGAKDGKNADGSDKFK \\
\hline $1923215 \mathrm{~A}$ & VSALKLTEYKGLRIEMDDN-YGSKLQEVKVYGDATG- - - - -SSFI \\
\hline ADA62505 & KGAIDKNVYKGLKVELEEKPNAGTLSFKKYYASSEK $-\cdots$ \\
\hline $\mathrm{ABB} 46200$ & DGAIDKTVYRGIKVELEEKPATGALSFKVYANSEK- - - - - - - \\
\hline ACA61140 & -SSMLTDVGEDVEVELTYKLDFTDYDDIQFMYNNG $\cdots$ \\
\hline C14B22 & DFDATTLGST-VLRITLQALEGTALTAKVNDAKLIKTDGSEVSG. \\
\hline ACA61137 & LFDTSILGST-FWGITLQTNAG - PLTAKVNKATLI KADGTEEELT \\
\hline $1923215 \mathrm{~A}$ & NFENAKTGST-VSRITLQTNVG - ATKAKINQVALI KSDNSEVKLS \\
\hline ADA62505 & AFSNYTG - - - IEKINLQWNVATKGSIKIKSNVNLVKHDNTLEPCG] \\
\hline ABB4 6200 & AFFSYTG- - - IQKINLQWNIATKGSIKIKSVNLIKHDDSTEPCS \\
\hline ACA61140 & AFDGADFSASSVYGIQSGDTKTSVLTFDASAYGYVSKYEMVIQGH \\
\hline C14B22 & KPTAIQRIHANQ - SVTDNTI YNLHGQRMQNPQKGIYIRNGKKYVM \\
\hline ACA61137 & - - TGIRSTKAVP -STGD - - IYDLSGRRVQNPQKGIYIKNGKKFVKQ \\
\hline $1923215 \mathrm{~A}$ & -VSGIHELHYTP-QTDN-RIYNLQGQQIAKPQRGIYIQNGKKFIAK \\
\hline ADA62505 & - - TGIESITTTP-RPTDGI I YNLSGQQVATPTHGIYIKSGKKY I KR \\
\hline ABB4 6200 & - - TGIEDITITPVRHDDGI I YNLSGQPVTSPQRGIYILNGKKI IK \\
\hline ACA61140 & - - SAI PLIKADY - - PDNTI I YNLNGQRVETPRKGIYIQNGKKYIA \\
\hline
\end{tabular}

Figure 4 Multiple sequence alignment of C-terminal module (amino acids 340-559) of Cel14b22 with xylanase/cellulase (1923215A, 375-584aa) from the ruminal bacterium Prevotella ruminicola 23 and uncultured ruminal microbial cellulases (ACA61137, aa 334-546; ACA61140, aa 334-537; ABB46200, aa 715-917; ADA 62505, aa 721-919). The nine conserved aromatic amino acid residues among homologous C-terminal modules are highlighted in bold and blue.

lichenan, perhaps due to the higher proportion of $\beta$-(1,3)-linkages in this polysaccharide. The Cel14b22 product could also hydrolyse birchwood xylan and oatspelt xylan, but had limited activity toward microcrystalline cellulose and filter paper, which are largely resistant to hydrolysis by many of the previously characterized $\mathrm{GH}$ 5 glucanases [30,35] including the metagenome-derived endoglucanase Cel5A [23]. The broad substrate specificity of Cel14b22 is consistent with previous reports on cellulases from other glucanase families [36-41]. Although the enzyme shows considerable homology (66\%) with another uncultured ruminal microbial cellulase [40], its enzymatic characteristics are quite different.

\section{Conclusions}

Our study confirmed the utility of a freeze grinding method for the isolation from a complex microbial community of high molecular weight metagenomic DNA for use in the construction of BAC libraries. Such libraries allow functional screening for the isolation of novel hydrolytic enzymes and facilitate the analysis of gene clusters containing functionally related genes that may or may not be expressed in the heterologous host. In addition we identified and characterized a novel family 5 glycoside hydrolase with significant activity towards a variety of $\beta-1,4$ - and $\beta-(1,3-1,4)$ glucans, including microcrystalline and filter paper celluloses, and $\beta-1,4$-xylans.

\section{Methods}

\section{DNA isolation from rumen samples}

Rumen contents (mixed solids and liquid) were sampled from a rumen cannulated dairy cow maintained on a grass/hay diet. The samples ( 15 g) were centrifuged (19 $200 \times \mathrm{g}, 10 \mathrm{~min}$ ), and the pellet suspended in $30 \mathrm{~mL}$ of $100 \mathrm{mM}$ Tris- $\mathrm{HCl} \mathrm{pH}$ 8.0, $500 \mathrm{mM}$ EDTA pH 8.0, $1.5 \mathrm{M} \mathrm{NaCl}, 1 \mathrm{mg} / \mathrm{mL}$ Proteinase $\mathrm{K}$ and rapidly frozen in liquid nitrogen. Frozen samples were pulverized in a Retsch RM 100 Mortar Grinder (F. Kurt Retsch $\mathrm{GmbH}$ and Co., Haan, Germany) and ground in the presence of liquid nitrogen for $5 \mathrm{~min}$. Following grinding, samples were incubated in a water bath at $50^{\circ} \mathrm{C}$ for $40 \mathrm{~min}$, combined with $3 \mathrm{~mL} 2 \%$ SDS and incubated at $65^{\circ} \mathrm{C}$ for another $45 \mathrm{~min}$. The lysate was centrifuged at $19200 \times \mathrm{g}$ for $10 \mathrm{~min}$ at room temperature to pellet debris and the supernatant was combined 1:1 (v/v) with warm $\left(65^{\circ} \mathrm{C}\right) 2 \%$ agarose $(\mathrm{w} / \mathrm{v}$ in distilled water) by gentle inversion. This mixture was poured into $90 \mathrm{~mm}$ square petri plates to a depth of 5-6 $\mathrm{mm}$ thickness and allowed to solidify at room temperature. The agarose containing the embedded DNA was then cut into $5 \mathrm{~mm}$ strips and the strips were equilibrated 3 times over $24 \mathrm{~h}$ against 30 volumes of TE buffer $(10 \mathrm{mM}$ Tris. $\mathrm{HCl}$, $1 \mathrm{mM}$ EDTA, $\mathrm{pH}$ 8.0) and stored at $4^{\circ} \mathrm{C}$. Low molecular weight DNA $(<25 \mathrm{~Kb})$ was removed by a single fractionation by field inversion gel electrophoresis in $1 \%$ agarose 
and $0.5 \times$ TBE using a Hoefer PC750 pulse controller (Hoefer Scientific Instruments, San Francisco, CA, USA) set at $3 \mathrm{~s}$ forward, $1 \mathrm{~s}$ reverse with a $0.5 \times / \mathrm{h}$ increasing time ramp, run at 4 V.cm-1 for $16 \mathrm{~h}$ at $4^{\circ} \mathrm{C}$. Fragments of DNA larger than $50 \mathrm{~Kb}$ were concentrated by electrophoresis at a constant $4 \mathrm{~V} / \mathrm{cm}$ onto a piece of $6000-$ $8000 \mathrm{Da}$ cutoff dialysis membrane secured in the gel at the $50 \mathrm{~Kb}$ point. After sufficient time to move all DNA to the membrane the field was reversed and the DNA run back off the membrane into the gel a distance of $2 \mathrm{~mm}$. The $3 \mathrm{~mm}$ strip of agarose containing the concentrated high molecular weight (50 to $\sim 500 \mathrm{~Kb}$ ) DNA was removed and stored in sterile TE buffer at $4^{\circ} \mathrm{C}$.

\section{Sau3AI digestion and DNA sizing}

Agarose containing 50-500 Kb rumen metagenomic DNA was equilibrated three times for $30 \mathrm{~min}$ in $1 \times \mathrm{New}$ England BioLabs buffer 1, $1 \times$ Bovine Serum Albumin (New England BioLabs, Pickering, ON, Canada). The agarose was then melted at $65^{\circ} \mathrm{C}$ for $5 \mathrm{~min}$, cooled to $37^{\circ} \mathrm{C}$, and Sau3AI (New England BioLabs) was added at a concentration of $0.01 \mathrm{U} / \mu \mathrm{L}$ of agarose. The mixture was incubated at $37^{\circ} \mathrm{C}$ for $10 \mathrm{~min}$ and digestion stopped by the addition of EDTA to a final concentration of $20 \mathrm{mM}$, producing a limited partial Sau3AI digest. The partially Sau3AI-digested DNA was then further sized as described above to remove fragments less than $50 \mathrm{~kb}$ before being used for ligation.

\section{BAC library construction}

Agarose containing partially digested and sized metagenomic DNA was equilibrated 3 times over $24 \mathrm{~h}$ in 10 volumes of TE. A portion was melted, diluted twofold and used to determine DNA concentration using a NanoDrop3300 fluorospectrometer (Thermo Scientific NanoDrop, Wilmington DE, USA). Metagenomic DNA (25-50 ng) in no more than $12.5 \mu \mathrm{L}$ of agarose was used in ligation reactions set up according to the manufacturer's directions using $25 \mathrm{ng}$ pSMART BAC vector (Lucigen Corporation, Middleton, WI, USA) in a final volume of $50 \mu \mathrm{L}$. Ligation reactions $(1 \mu \mathrm{L})$ were transformed into $20 \mu \mathrm{L}$ of BAC-Optimized Replicator v2.0 Electrocompetent Cells (Lucigen Corporation) in a $1 \mathrm{~mm}$ gap cuvette using a BTX ECM 600 (BTX Harvard Apparatus, Holliston MD, USA) set with a resistance of $129 \mathrm{ohms}$ and charging voltage of $1.2 \mathrm{kV}$. Positive transformants were selected on YT agar ( $0.8 \mathrm{~g}$ tryptone, $0.5 \mathrm{~g}$ yeast extract, $0.5 \mathrm{~g} \mathrm{NaCl}, 1.2 \mathrm{~g}$ agar per $100 \mathrm{~mL}$ water) containing $5 \%$ sucrose and $12.5 \mu \mathrm{g} / \mathrm{mL}$ chloramphenicol. Positive clones were picked using a Genetix QPix (Genetix, San Jose CA, USA) into 384 well plates containing Luria-Bertani (LB) freezing medium (1.0 g tryptone, 0.5 g yeast extract, $1.0 \mathrm{~g} \mathrm{NaCl}, 0.18 \mathrm{~g} \mathrm{H}_{2} \mathrm{PO} 4$, $0.67 \mathrm{~g} \mathrm{~K}_{2} \mathrm{HPO} 4,0.05 \mathrm{~g}$ sodium citrate, $0.09 \mathrm{~g}\left(\mathrm{NH}_{4}\right)_{2} \mathrm{SO}_{4}$,
$4.4 \mathrm{~mL}$ glycerol, $20 \mu \mathrm{L} 5 \mathrm{~N} \mathrm{NaOH}$, per $100 \mathrm{~mL}$ water). After autoclaving sterile $\mathrm{Mg} \mathrm{SO}$ was added to a final concentration of $0.4 \mathrm{mM}$ containing $12.5 \mu \mathrm{g} / \mathrm{mL}$ chloramphenicol and clones were cultured overnight at $37^{\circ} \mathrm{C}$ before storing at $-80^{\circ} \mathrm{C}$.

\section{Screening for clones expressing hydrolase activities}

Cultures stored in LB freezing medium were replicated into $\mathrm{LB}$ with $12.5 \mu \mathrm{g} / \mathrm{mL}$ chloramphenicol in 384 well plates and grown overnight at $37^{\circ} \mathrm{C}$. Clones were transferred from the 384 well plates onto $22 \mathrm{~cm} \times 22 \mathrm{~cm}$ plates containing LB agar overlaid with a $1 \mathrm{~mm}$ deep layer of agar containing the test substrate, in a $3 \times 3$ macroarray grid pattern using a Genetix QPix, such that each individual clone was inoculated twice in each $3 \times 3$ grid. A maximum of 6912 clones were screened on each $22 \mathrm{~cm} \times 22 \mathrm{~cm}$ plate.

Polysaccharide hydrolase activities were detected using the method of Wood et al. [41] with overlays containing carboxymethyl cellulose (CMC) (Sigma-Aldrich, Oakville, ON, Canada), oat $\beta$ glucan, lichenan (Sigma-Aldrich), or corn xylan (Sigma-Aldrich) at a $1 \%$ concentration, followed by staining with Congo red to visualize clearing zones. ß-glucosidase activity was evaluated using plates containing $0.1 \%$ esculin and $0.05 \%$ ferric ammonium citrate in the overlay and observing a black precipitate around clones positive for $ß$-glucosidase activity [42].

\section{BAC sequencing and analysis}

BAC clones expressing positive cellulase activities were selected for shotgun 454 sequencing (Macrogen, Seoul, Korea). Sequence data was assembled using Mira3 [43] after vector sequences were masked using the program Smalt (Wellcome Trust Sanger Institute, Cambridge, UK). Assembled contigs were imported into Geneious [44] (Biomatters Ltd., Auckland, New Zealand) and open reading frames were identified using open reading frame finder (NCBI; http://www.ncbi.nlm.nih.gov) and Glimmer [45] Sequences identities were investigated using BlastN, BlastX and BlastP (NCBI; http://www.ncbi.nlm.nih.gov) and genome comparisons were made using IMG and IMG/M [46]. The modular structures of the enzymes were predicted by SMART online (http://smart.emblheidelberg.de). The nucleotide sequence of the cellulase gene (Cel14b22) was deposited into the GenBank database under accession number JN98181.

\section{Subcloning and characterization of cellulase activities}

Subcloning was performed to localize the hydrolase genes, to shorten the inserts for effective sequencing, and to increase expression levels for biochemical characterization. Extracted BAC DNA was obtained from hydrolasepositive clones using a large and partial digest with Sau3AI. Fragments between 2 and $8 \mathrm{~kb}$ were extracted 
from agarose gel with a QIAquick Gel Extraction Kit (Qiagen, Mississauga, ON, Canada) according to the manufacturer directions and subcloned into BamHI digested, calf intestinal phosphatase dephosphorylated plasmid vector pUC19 (Invitrogen, Burlington, ON, Canada). The resulting transformants were screened for cellulase activity as described above. Ten subclones expressing different $\mathrm{CMC}$ hydrolases (CMCases) were identified and grown in 200-mL cultures overnight. The cells were harvested by centrifugation $(8000 \times \mathrm{g}, 15 \mathrm{~min})$, resuspended in $4 \mathrm{~mL}$ of $0.1 \mathrm{M}$ sodium-phosphate buffer (pH 6.5) and lysed by sonication. Crude cell lysates were centrifuged at $10000 \times \mathrm{g}$ for $20-30 \mathrm{~min}$ at $4^{\circ} \mathrm{C}$ to remove cellular debris and supernatants were used as crude protein extracts for subsequent assays. $\mathrm{pH}$ profiles for individual subclones was determined at $40^{\circ} \mathrm{C}$ by monitoring enzyme activity over a range of $\mathrm{pHs}(0.1 \mathrm{M}$ citric acidsodium citrate buffer, $\mathrm{pH}$ 3.0 6.0; $0.1 \mathrm{M}$ sodiumphosphate buffer, pH 6.0 8.0; $0.1 \mathrm{M}$ glycine- $\mathrm{NaOH}$ buffer, $\mathrm{pH}$ 8.6 10.0). Optimal activity over a temperature range of $25^{\circ} \mathrm{C}$ to $75^{\circ} \mathrm{C}$ was also determined. To analyse substrate specificities, the hydrolase activity of the protein extracts was measured after $30 \mathrm{~min}$ incubation at the optimal temperature in the optimal buffer containing $1 \%(\mathrm{w} / \mathrm{v})$ polysaccharides. The tested polysaccharides were $\mathrm{CMC}$, Avicel, lichenan, barley glucan, methyl cellulose, oat spelt xylan, birch wood xylan, oat gum, and filter paper. Reducing sugars released from the substrates were measured with 3,5-dinitrosalicylic acid as described by Miller [47]. One unit (U) of endoglucanase activity was defined as the amount of enzyme releasing $1 \mu \mathrm{mol}$ of reducing sugar per min from the substrate. Equal amounts of protein were added to each reaction and the highest enzymatic activity towards a substrate for each crude enzyme extract from each subclone was used as benchmark of $100 \%$ activity.

\section{SDS-PAGE gel electrophoresis, native PAGE and hydrolase zymography}

Sodium dodecyl sulfate polyacrylamide gel electrophoresis (SDS-PAGE) was performed according to the method of Laemmli [48]. Native PAGE was carried out similarly with the exclusion of SDS from all solutions. For zymogram analysis of endoglucanases, the gel was placed on a fresh $1 \%$ agar plate containing $0.2 \%(\mathrm{w} / \mathrm{v}) \mathrm{CMC}$, and the covered plate was incubated at $37^{\circ} \mathrm{C}$ for $1 \mathrm{~h}$ followed by staining and destaining with Congo Red as described above for library screening.

\section{Expression and purification of recombinant enzyme Cel14b22}

The endoglucanase gene harboured in BAC clone 14b22 (subclone p13), designated Cel14b22, was amplified by polymerase chain reaction (PCR) with the primers $5^{\prime}$
GGAAGATCTTATGAAGAAAATTCTACT -3' (forward) and 5'-CCGGAATTCTTATTTCATAACGTATT -3' (reverse). PCR product was digested with BglII and EcoRI and ligated into the expression vector pET-30a $(+)$ for expression of the recombinant protein with an $\mathrm{N}$-terminal 6-His tag. The resulting expression construct was transformed into Escherichia coli BL21(DE3) and positive clones were selected on plates containing kanamycin. Cells were grown in LB broth containing $25 \mathrm{mg} / \mathrm{mL}$ of kanamycin at $37^{\circ} \mathrm{C}$ with shaking at $200 \mathrm{rpm}$ and protein expression was induced with $1 \mathrm{mM}$ IPTG (final concentration) when an optical density $(600 \mathrm{~nm})$ of 0.6 was reached. Protein expression was carried out at room temperature for 3-5 h. Cells were harvested by centrifugation $(5000 \times \mathrm{g}$, $15 \mathrm{~min})$, resuspended in lysis buffer $\left(0.05 \mathrm{M} \mathrm{NaH}_{2} \mathrm{PO}_{4}\right.$; $\mathrm{pH} 8.0,0.300 \mathrm{M} \mathrm{NaCl}, 0.02 \mathrm{M}$ imidazole) and lysed by sonication. Cell debris were pelleted by centrifugation (30 $000 \times \mathrm{g}$ for $30 \mathrm{~min}$ ) and the supernatant was loaded onto a $2 \mathrm{~mL}$ Ni-NTA (nickel-nitrilotriacetic acid) column. The imidazole concentration was increased to $0.04 \mathrm{M}$ and the resin was washed with $10 \mathrm{~mL}$ of buffer. Protein was eluted by increasing the imidazole to $0.25 \mathrm{M}$ in the final wash. The final purified protein solution was desalted using a PD-10 ultrafiltration column (GE Healthcare, Mississauga, ON, Canada) by gravity flow according to the manufacturer's directions and eluted with $0.05 \mathrm{M}$ citrate-phosphate buffer, $\mathrm{pH}$ 6.0. Protein concentration was determined using a Quick Start Bradford Protein Assay kit (Bio-Rad, Mississauga, ON, Canada).

\section{Characterization of Cel14b22 activities}

Cellulase activity was measured by incubating $0.7 \mu \mathrm{g}$ of recombinant Cel14b22 with $1 \%$ CMC in $0.5 \mathrm{~mL} 0.1 \mathrm{M}$ citrate phosphate buffer, $\mathrm{pH} 6.0$, at $50^{\circ} \mathrm{C}$ for $15 \mathrm{~min}$. Optimal $\mathrm{pH}$ and temperature were determined as described above. Substrate specificities of the enzyme and the effect of several metal chloride salts at $10 \mathrm{mM}(\mathrm{Ca}, \mathrm{Co}, \mathrm{Cr}$, $\mathrm{Cu}, \mathrm{Fe}, \mathrm{K}, \mathrm{Mg}, \mathrm{Mn}, \mathrm{Na}, \mathrm{Zn}$ ), a chelating agent (EDTA) at $1 \mathrm{mM}$, and the detergent SDS at $1 \%(\mathrm{w} / \mathrm{v})$ were investigated at optimal $\mathrm{pH}(6.0)$ and temperature $\left(50^{\circ} \mathrm{C}\right)$. The $\mathrm{pH}$ stability was determined by measuring residual cellulase activity after the enzyme was incubated at $4^{\circ} \mathrm{C}$ for $24 \mathrm{~h}$ at the test $\mathrm{pH}$. Thermal stability data were compared after incubating the enzyme at various temperatures from 30 to $70^{\circ} \mathrm{C}$ for $1 \mathrm{~h}$, and measuring the residual cellulase activity. The kinetic constants, $K_{m}$ and $V_{\text {max }}$, were calculated by directly fitting the data to the Michaelis-Menten equation by nonlinear regression. Reactions were carried out under optimal condition with CMC of different concentrations, ranging from 5 to $35 \mathrm{mg} / \mathrm{mL}$.

\section{Abbreviations}

BAC: Bacterial artificial chromosome; CBM: Carbohydrate binding module; CMC: Carboxymethylcellulose; EDTA: Ethylenediaminetetraacetic acid; 
GH: Glycosyl hydrolase; SDS-PAGE: Sodium dodecyl sulfate polyacrylamide gel electrophoresis; Ni-NTA: Nickel-nitriloacetic acid.

\section{Competing interests}

The authors declare no competing interests.

\section{Authors' contribution}

XG carried out functional screening and characterized the enzymes. LP isolated metagenomic DNA and constructed the BAC library. RG and SQ analysed data and wrote the manuscript. RF, TM, RT conceived of the study and participated in its design and coordination and helped to draft the manuscript. All authors read and approved the final manuscript.

\section{Acknowledgements}

This work was conducted under the research fund from the Agricultural Bioproducts Initiative Program (ABIP) Cellulosic Biofuels Network (CBioN) of Agriculture and Agri-Food Canada and the Genozymes project with funding from Genome Alberta. The authors gratefully thank L. L. You and Krysty Munns for technical support.

\section{Author details}

${ }^{1}$ Agriculture and Agri-Food Canada, Lethbridge Research Centre, Lethbridge, Alberta T1J 4B1, Canada. ${ }^{2}$ Feed Research Institute, Chinese Academy of Agricultural Sciences, Beijing, China.

Received: 19 June 2012 Accepted: 8 October 2012

Published: 13 October 2012

\section{References}

1. Lynd LR, van Zyl WH, McBride JE, Laser M: Consolidated bioprocessing of cellulosic biomass: an update. Curr Opin Biotechnol 2005, 16:557-583.

2. Bhat MK: Cellulases and related enzymes in biotechnology. Biotechnol Adv 2000, 18:355-383.

3. Kristensen JB, Thygesen LG, Felby C, Jørgensen H, Elder T: Cell-wall structural changes in wheat straw pretreated for bioethanol production. Biotechnol Biofuels 2008, 1:5-13.

4. Russell JB, Rychlik JL: Factors that alter rumen microbial ecology. Science 2001, 292:1119-1122.

5. Krause DO, Denman SE, Mackie RI, Morrison M, Rae AL, Attwood GT, McSweeney CS: Opportunities to improve fiber degradation in the rumen: microbiology ecology and genomics. FEMS Microbiol Rev 2003, 27:663-693.

6. Pace NR: A molecular view of microbial diversity and the biosphere. Science 1997, 276:734-740.

7. Rondon MR, Goodman RM, Handelsman J: The Earth's bounty: assessing and accessing soil microbial diversity. Trends Biotechnol 1999, 17:403-409.

8. Kocherginskaya SA, Aminov RI, White BA: Analysis of the rumen bacterial diversity under two different diet conditions using denaturing gradient gel electrophoresis random sequencing and statistical ecology approaches. Anaerobe 2001, 7:119-134.

9. Galbraith EA, Antonopoulos DA, White BA: Suppressive subtractive hybridization as a tool for identifying genetic diversity in an environmental metagenome: the rumen as a model. Environ Microbiol 2004, 6:928-937.

10. Edwards E, McEwan R, Travis A, Wallance R: 16S rDNA library-based analysis of ruminal bacterial diversity. Antonie Van Leeuwenhoek 2004, 86:263-281.

11. Shin EC, Cho KM, Lim WJ, Hong SY, An CL, Kim EJ, Kim YK, Choi BR, An JM, Kang JM, Kim H, Yun HD: Phylogenetic analysis of protozoa in the rumen contents of cow based on the 18S rDNA sequences. J Appl Microbiol 2004, 97:378-383.

12. Ohene-Adjei S, Chaves AV, McAllister TA, Benchaar C, Teather RM, Forster RJ: Evidence of increased diversity of methanogenic archaea with plant extract supplementation. Microb Ecol 2008, 56:234-242.

13. Tringe SG, von Mering C, Kobayashi A, Salamov AA, Chen K, Chang HW, Podar M, Short JM, Mathur EJ, Detter JC, Bork P, Hugenholtz P, Rubin EM: Comparative metagenomics of microbial communities. Science 2005, 308:554-557.

14. Ferrer M, Golyshina OV, Chernikova TN, Khachane AN, Reyes-Duarte D, Santos VA, Strompl C, Elborough K, Jarvis G, Neef A, Yakimov MM, Timmis
KN, Golyshin PN: Novel hydrolase diversity retrieved from a metagenome library of bovine rumen microflora. Environ Microbiol 2005, 7:1996-2010.

15. Lorenz P, Eck J: Metagenomics and industrial applications. Nat Rev Microbiol 2005, 3:510-516.

16. Brulc JM, Antonopoulos DA, Miller ME, Wilson MK, Yannarell AC, Dinsdale EA, Edwards RE, Frank ED, Emerson JB, Wacklin P, Coutinho PM, Henrissat B, Nelson KE, White BA: Gene-centric metagenomics of the fiber-adherent bovine rumen microbiome reveals forage specific glycoside hydrolases. Proc Natl Acad Sci USA 2009, 106:1948-1953.

17. Hess M, Sczyrba A, Egan R, Kim TW, Chokhawala H, Schroth G, Luo S, Clark DS, Chen F, Zhang T, Mackie RI, Pennacchio LA, Tringe SG, Visel A, Woyke T, Wang Z, Rubin EM: Metagenomic discovery of biomass-degrading genes and genomes from cow rumen. Science 2011, 331:463-467.

18. Warnecke F, Luginbühl $P$, Ivanova N, Ghassemian M, Richardson TH, Stege JT, Cayouette M, McHardy AC, Djordjevic G, Aboushadi N, Sorek R, Tringe SG, Podar M, Martin HG, Kunin V, Dalevi D, Madejska J, Kirton E, Platt D, Szeto E, Salamov A, Barry K, Mikhailova N, Kyrpides NC, Matson EG, Ottesen EA, Zhang X, Hernández M, Murillo C, Acosta LG, Rigoutsos I, Tamayo G, Green BD, Chang C, Rubin EM, Mathur EJ, Robertson DE, Hugenholtz P, Leadbetter JR: Metagenomic and functional analysis of hindgut microbiota of a wood-feeding higher termite. Nature 2007, 450:560-565.

19. Zhu L, Wu Q, Dai J, Zhang S, Wei F: Evidence of cellulose metabolism by the giant panda gut microbiome. Proc Natl Acad Sci USA 2011, 108:17714-177149.

20. Suen G, Weimer PJ, Stevenson DM, Aylward FO, Boyum J, Deneke J, Drinkwater C, Ivanova NN, Mikhailova N, Chertkov O, Goodwin LA, Currie $C R$, Mead D, Brumm PJ: The complete genome sequence of Fibrobacter succinogenes $\mathrm{S} 85$ reveals a cellulolytic and metabolic specialist. PLOS One 2011, 6:1-15.

21. Sakon J, Adney WS, Himmel ME, Thomas SR, Karplus PA: Crystal structure of thermostable family 5 endocellulase E1 from Acidothermus cellulolyticus in complex with cellotetraose. Bjochemistry 1996, 35:10648-10660.

22. Lo Leggio L, Larsen S: The $1.62 \AA$ structure of Thermoascus aurantiacus endoglucanase: completing the structural picture of subfamilies in glycoside hydrolase family 5. FEBS Lett 2002, 523:103-108.

23. Duan CJ, Liu JL, Wu X, Tang JL, Feng JX: A novel carbohydrate-binding module identified in a ruminal metagenomic endoglucanase. Appl Environ Microbiol 2010, 76:4867-4870.

24. Simpson PJ, Xie HF, Bolam DN, Gilbert HJ, Williamson MP: The structural basis for the ligand specificity of family 2 carbohydrate-binding modules. J Biol Chem 2000, 275:41137-41142.

25. Linder $M$, Teeri $\Pi$ : The roles and function of cellulose-binding domains. J Biotechnol 1997, 57:15-28.

26. Macarron R, Acebal C, Castillon MP, Dominguez JM, de la Mata I, Pettersson G, Tomme P, Claeyssens M: Mode of action of endoglucanase III from Trichoderma reesei. Biochem J 1993, 289:867-873.

27. Cavicchioli R, Watson K: Molecular cloning expression and characterization of endoglucanase genes from fibrobacter succinogenes ARI. Appl Environ Microbiol 1991, 57:359-365.

28. Sheweita SA, Ichi-lshi A, Park JS, Liu C, Malburg LM, Doi RH: Characterization of eng $\mathrm{F}$ a gene for a non-cellulosomal Clostridium cellulovorans endoglucanase. Gene 1996, 182:163-167.

29. Chauvaux S, Beguin P, Aubert JP, Bhat KM, Gow LA, Wood TM, Bairoch A: Calcium-binding affinity and calcium-enhanced activity of Clostridium thermocellum endoglucanase D. Biochem J 1990, 265:261-265.

30. Béra-Maillet C, Arthaud L, Abad P, Rosso MN: Biochemical characterization of MI-ENG1 a family 5 endoglucanase secreted by the root-knot nematode Meloidogyne incognita. Eur J Biochem 2000, 267:3255-3263.

31. Voget S, Steele HL, Streit WR: Characterization of a metagenome-derived halotolerant cellulose. J Biotechnol 2006, 126:26-36.

32. Feng Y, Duan CJ, Pang H, Mo XC, Wu CF, Yu Y, Hu YL, Wei J, Tang JL, Feng $J X$ : Cloning and identification of novel cellulase genes from uncultured microorganisms in rabbit cecum and characterization of the expressed cellulases. Appl Microbiol Biotechnol 2007, 75:319-328.

33. Pang H, Zhang P, Duan CJ, Mo X, Ch Tang JL, Feng JX: Identification of cellulase genes from the metagenomes of compost soils and functional characterization of one novel endoglucanase. Curr Microbiol 2009, 58:404-408.

34. Rubini MR, Dillon AJP, Kyaw CM, Faria FP, Poças-Fonseca MJ, Silva-Pereira I: Cloning characterization and heterologous expression of the first Penicillium echinulatum cellulase gene. J Appl Microbiol 2009, 108:1187-1198.

35. Fontes CM, Clarke JH, Hazlewood GP, Fernandes TH, Gilbert HJ, Ferreira LM: Possible roles for a non-modular thermostable and proteinase-resistant 
cellulase from the mesophilic aerobic soil bacterium Cellvibrio mixtus. Appl Microbiol Biotechnol 1997, 48:473-479.

36. Wang WY, Reid SJ, Thomson JA: Transcriptional regulation of an endoglucanase and a cellodextrinase gene in Ruminococcus flavefaciens. J Gen Microbiol 1993, 139:1219-1226.

37. Han SJ, Yoo YJ, Kang HS: Characterization of a bifunctional cellulase and its structural gene the cell gene of Bacillus sp D04 has exo- and endoglucanase activity. J Biol Chem 1995, 270:26012-26019.

38. Cho KM, Hong SY, Lee SM, Kim YH, Kahng GG, Kim H, Yun HD: A cel44C man26A gene of endophytic Paenibacillus polymyxa GS01 has multiglycosyl hydrolases in two catalytic domains. Appl Microbiol Biotechnol 2006, 73:618-630.

39. Kim YG, Choi G, Kim S, Yoon G, Kim Y, Ryu Y: Screening and characterization of a novel esterase from a metagenomic library. Protein Expr Purif 2006, 45:315-323.

40. Duan CJ, Xian L, Zhao GC, Feng Y, Pang H, Bai JL, Tang QS, Feng JX: Isolation and partial characterization of novel genes encoding acidic cellulases from metagenomes of buffalo rumens. J Appl Microbiol 2009, 107:245-256.

41. Wood PJ, Erfle JD, Teather RM: Use of complex formation between congo red and polysaccharides in the detection and assay of polysaccharide hydrolases. Meth Enzymol 1988, 160:59-74.

42. Eberhart B, Cross DF, Chase LR: $\beta$-Glucosidase system of Neurospora crassa I $\beta$-Glucosidase and cellulase activities of mutant and wild-type strains. J Bacteriol 1964, 87:761-770.

43. Chevreux B, Wetter T, Suhai S: Genome sequence assembly using trace signals and additional sequence information. Comput Sci Biol 1999, 99:45-56.

44. Drummond AJ, Ashton B, Buxton S, Cheung M, Cooper A, Duran C, Field M, Heled J, Kearse M, Markowitz S, Moir R, Stones-Havas S, Sturrock S, Thierer T, Wilson A: Geneious v5 4. [http://www.geneious.com/]

45. Delcher AL, Bratke KA, Powers EC, Salzberg SL: Identifying bacterial genes and endosymbiont DNA with Glimmer. Bioinformatics 2007, 15:673-679.

46. Markowitz VM, Ivanova NN, Szeto E, Palaniappan K, Chu K, Dalevi D, Chen IM, Grechkin Y, Dubchak I, Anderson I, Lykidis A, Mavromatis K, Hugenholtz P, Kyrpides NC: IMG/M: a data management and analysis system for metagenomes. Nucleic Acids Res 2008, 36:534-538.

47. Miller GL: Use of dinitrosalicylic acid reagent for determination of reducing sugar. Anal Chem 1959, 31:426-428.

48. Laemmli UK: Cleavage of structural proteins during the assembly of the head of bacteriophage T4. Nature 1970, 227:680-685.

doi:10.1186/1756-0500-5-566

Cite this article as: Gong et al:: Cloning and identification of novel hydrolase genes from a dairy cow rumen metagenomic library and characterization of a cellulase gene. BMC Research Notes 2012 5:566.

\section{Submit your next manuscript to BioMed Central and take full advantage of:}

- Convenient online submission

- Thorough peer review

- No space constraints or color figure charges

- Immediate publication on acceptance

- Inclusion in PubMed, CAS, Scopus and Google Scholar

- Research which is freely available for redistribution 